NOTES ON THE MARANTACEAE OF SURINAME

BY

\author{
A. M. E. JONKER-VERHOEF AND F. P. JONKER \\ (Botanical Museum and Herbarium, Utrecht)
}

(received February 15th, 1955)

The list of Marantaceae published by Pulle (1906) comprises 20 species belonging to 6 genera, the largest genus being Calathea with 8 species. It was found, however, that one of the species does not belong to the family: investigation of the type of Calathea strobilifera (Miq.) Koern., viz. Kegel 1469 [GOET], showed that it pertains to Renealmia strobilifera Poepp. et Endl. (Zingiberaceae). The record of another species, Calathea allouia (Aubl.) Lindl. appeared to be based on a misidentification: the collection Focke 893 cited under this name by Pulle (1906) belongs to C. grandis O. G. Peters. Later on Pulle (1909) recorded the occurrence of one species more of this family in Suriname, viz. Myrosma polystachya Pulle, a new species. Since then no further additions to the list of Suriname species have been published.

Our investigation of the Suriname material showed the occurrence of 33 species belonging to 8 genera. In the following pages a few taxonomic and phytogeographical remarks are made on some of these genera and species; they also contain the description of a new genus.

CALATHEA G. F. W. Mey.

As mentioned above we had to remove from Pulle's list two species: Calathea allouia (Aubl.) Lindl. and C. strobilifera (Miq.) Koern. To the remaining 6 species we are adding 6 other ones, recorded for the first time from Suriname, viz.:

1. C. lutea (Aubl.) Spreng., once collected by the Forestry Department in the Wilhelmina Mountains; it was already known from the WestIndian Islands and tropical America.

2. C. legrelleana Reg., already collected by Splitgerber in 1838 but overlooked by PULLE; since then two other collections have been added. This species has been recorded from Ecuador, Colombia and Amazonian Brazil.

3. C. cyclophora Baker, hitherto known only from British Guiana, but recently collected four times by Lanjouw and Lindeman in Suriname. 
Our investigation of the material in the Paris herbarium showed that this species occurs in French Guiana too, where it was collected by Leprieur and by Richard.

4. C. micans (Kl.) Koern., known before from Nicaragua, Guatemala, French and British Guiana, Amazonian Brazil, Colombia and Peru. In our opinion $C$. albicans Brogn. ex K. Schum. = C. micans var. robustior Koern. is to be considered a synonym. Both taxa have been based on specimens of a somewhat more robust growth.

5. C. ovata (Nees et Mart.) Lindl., a species up till now known only from Brazil, Bahia. Tubers of this species were collected by GeIJskes at Mt. Temomairem, Toemoek Hoemak Mts., Upper Litanie River, and brought to Paramaribo where they were planted in the garden of the Agricultural Experimental Station; flowering plants gathered there were studied by us. The tubers are said to be eaten by the Wama or Wayaré hoelé indians. The plants are known to them as "oeroewa" and to the Oajana indians as "pisoi". The Wama indians have no agriculture; the edible tubers are collected from the wild plants, see GeIJSKEs (1942). It is remarkable that the species has never been reported from the area between southern Suriname and Ilheos, Bahia, where the type and the other material known up till now were collected. 6. C. mansonis Koern. This species known from Bolivia, Brazil and French Guiana was collected in Suriname already about a century ago by Dr Voltz, later on it was collected again. The Voltz collection was regarded by Pulle (1906) as belonging to C. propinqua (Poepp. et Endl.) Koern.; the two species, indeed, show a close resemblance. C. mansonis is more robust and its inflorescence is always borne by a scape, but the latter may be very short. The inflorescence of $C$. propinqua is always sessile. The flowers of $C$. mansonis are more conspicuously pilose and their corolla tube is circ. four times as wide as that of $C$. propinqua. The corolla tube of $C$. propinqua is more than twice as long as the petals; in $C$. mansonis it is but slightly longer than the petals. The latter are slightly wider in $C$. propinqua. $C$. propinqua is known also from Amazonian Brazil and French Guiana. We are inclined, but before more material is known do not yet feel entitled, to consider $C$. mansonis a variety of $C$. propinqua.

C. villosa Lindl., known from Panama, Costa Rica, Colombia, Venezuela, Amazonian Brazil and British Guiana, is to be expected in Suriname.

\section{MARANTA L.}

In the genus Maranta Pulle (1906) listed two species, viz. $M$. arundinacea L. and $M$. divaricata Roscoe. We are adding two more species:

1. M. orbiculata (Koern.) K. Schum., once collected in Suriname by Rombouts at the Upper Sipaliwini River. Before it had been collected in Brazil only.

2. M. humilis Aubl. This species was collected by J. and P. A. Florschütz in 1951 between Ebba top and Pakka Pakka, Saramacca 
River. It was described from French Guiana by Aublet (1775) and, as far as we know, not collected again afterwards, though it was cited by KLotzsch (1848) for British Guiana. The Florschütz collection, though more robust, is undoubtedly conspecific with the Aublet specimen; the latter was studied by us from the Rousseau herbarium, recently purchased by the Paris herbarium, vid. LANJOuw \& UITTIEN (1940). As this species was unknown to K. Schumann (1902), the last monographer of the family, we wish to state that it belongs to the subgenus Koernickea $\mathrm{K}$. Schum. It shows a close affinity to $M$. longipes K. Schum., but differs by the presence of a petiole (between sheath and pulvinus), by the shorter peduncle and by the longer petals and staminodes. The number of floral bracts is in $M$. humilis always four and in $M$. longipes more than four.

\section{MONOPHYLLANTHE K. Schum.}

The only species of this genus, $M$. oligophylla $\mathrm{K}$. Schum., once before collected, viz. by Sagot in French Guiana, appears to have been collected three times in Suriname: once by Hulk at the Upper Gran Rio and twice by J. and P. A. Florschütz, respectively on the Brownsberg and at the Avanavero falls, Kabalebol River. As comparison with our own description in the "Flora of Suriname" will show, neither the floral characters nor the morphology of the inflorescence were correctly described by K. SchumanN (1902), the author of the genus, but as the differences with its allies are still sufficiently marked, we have maintained it.

\section{MYROSMA L. f. and HYLAEANTHE Jonk. et Jonk.}

The type of the genus Myrosma originated from Suriname where it was collected by Dalberg. The genus is characterized by the structure of the outer whorl of the androecium, which consists of two staminodes, by its very short corolla tube and by the persistent, coriaceous floral bracts, which subtend two or more flower pairs.

Pulle (1909) described a new species from Suriname, Myrosma polystachya Pulle, characterized by its inflorescence. He stated that one of the two outer staminodes was very small or absent. This species was up till now not collected again in Suriname; as far as we know it has been collected once in French Guiana (Geay 855 [P]). In our investigation of the type material we failed to observe the second outer staminode. Moreover we observed a striking resemblance in flower structure, in general habit and in the way in which the leaf sheaths decay into a reticulate mass of fibres, with Myrosma hexantha (Poepp. et Endl.) K. Schum., described by its authors in the genus Thalia, transferred by D. Dietrich (1839) to Maranta and, by K. Schumann (1902) in his monograph of the family, to Myrosma. The same holds for Myrosma unilateralis (Poepp. et Endl.) K. Schum. Both $M$. hexantha and $M$. unilateralis, originally described from Peru by Poeppig and Endlicher (1838), appear to occur in Suriname too. 
$M$. hexantha which is also known from Brazil, was collected at the Corantijne River by Hulk and in the Nassau Range by Lanjouw and Lindeman; $M$. unilateralis, known before from Peru only, was collected by the Forestry Department along Coppename creek, Lucie River, during the expedition to the Wilhelmina Mountains, 1926. The three species have chartaceous, oblong leaf blades, which are acuminate or apiculate at the apex and cuneate at the base. Their lower surface is light coloured and their margins are in herbarium material involute. Moreover the floral bracts are not coriaceous and the corolla tube is of the same length as the calyx or slightly shorter, but not, as in Myrosma, very short.

The generic limits of the genus Myrosma and several related genera are not always well defined and often inapplicable, as was pointed out also by Woodson (1942), p. 333.

For all these reasons we feel entitled to unite $M$. polystachya, $M$. hexantha, M. unilateralis, as well as $M$. hoffmannii K. Schum. from Costa Rica into a new genus Hylaeanthe. We select $M$. hexantha, as it has been most often collected, as the type species.

Hylaeanthe Jonk. et Jonk., gen. nov. Folia rosulata, petiolo ad 2 cm longo instructa; pulvinus ad $6 \mathrm{~mm}$ longus; vagina membranacea ultimo in fibrillos reticulatos dissoluta; lamina chartacea, oblonga, subtus pallidior, basi cuneata, in sicco margine involutus. Bractaea herbacea. Paris florum pedunculati 3 vel ultra. Flores pedicellati; corollae tubus sepalis subaequilongus; staminodium exterius 1; staminodium cucullatum appendiculo pendulo obtuso instructum; stamen appendiculo petaloideo antheram superante munitum; ovarium imperfecte triloculare; loculus fertilis 1 ; ovulum basale solitarium.

Typus: Hylaeanthe hexantha (Poepp. et Endl.) Jonk. et Jonk. = Thalia hexantha Poepp. et Endl. = Maranta hexantha (Poepp. et Endl.) D. Dietr. = Myrosma hexantha (Poepp. et Endl.) K. Schum.

Species 4:

1. Hylaeanthe hexantha (Poepp. et Endl.) Jonk. et Jonk., vide supra.

2. Hylaeanthe unilateralis (Poepp. et Endl.) Jonk. et Jonk. = Thalia unilateralis Poepp. et Endl. = Maranta unilateralis (Poepp. et Endl.) D. Dietr. = Saranthe unilateralis (Poepp. et Endl.) Eichl. = Myrosma unilateralis (Poepp. et Endl.) K. Schum.

3. Hylaeanthe hoffmannii (K. Schum.) Jonk. et Jonk. $=$ Myrosma hoffmannii K. Schum.

4. Hylaeanthe polystachya (Pulle) Jonk. et Jonk. = Myrosma polystachya Pulle.

We named the genus after the "hylaea" in which the species occur, adding the suffix "anthe" to bring it in accordance with similar generic names in the family e.g. Ctenanthe, Saranthe, Stromanthe. 


\section{THALIA L.}

Pulle (1906) mentioned for Suriname a single species, Thalia geniculata L., known from tropical and subtropical America. Both Mr N. Y. Sandwith, Kew Herbarium, and Mr N. W. Simmonds, Trinidad, drew our attention to Thalia trichocalyx, described by GaGNEPAIN (1904) from Mexico and French Guiana, from T. geniculata differing by shorter internodes between the floral bracts, much smaller flowers and floral bracts, sepals provided with long, slender, white hairs, and a horse-shoe-shaped aril.

According to Mr Simmonds T. geniculata is in the field easily distinguishable by its stouter, not taller, appearance and by the sterile bracts being red or purple beneath. In Trinidad both species grow together. After examining the material we quite agree with this distinction and we were much surprised to observe that most of the Suriname material belongs to T.trichocalyx. T. geniculata apparently does occur in Suriname, but this species has been collected only three times and that was a century ago (Splitgerber 169 [L], Kegel 603 [GoET], Hostmann 433 $[\mathrm{K}])$.

\section{ISGHNOSIPHON Koern.}

Pulle (1906) mentioned 4 species, one of which, viz. I. violaceus Pulle, was described as new. The latter has been collected again by J. and P. A. Florschütz in 1951; up till now it is not recorded from other countries.

It is closely related to $I$. martianus Eichl., a less tall species, differing by the membranous margin of its leaf sheath which in herbarium material is chestnut-coloured, by its shorter leaf sheath, the very short or absent petiole, the shorter pulvinus, the more narrow and slightly shorter leaf blade, the much shorter peduncles and the slightly longer corolla tube. The latter species, known from Brazil and French Guiana, was recently for the first time collected in Suriname by Lindeman at Ricanau, Cottica River.

I. surinamensis (Miq.) Koern., cited by Pulle and by all monographers, is regarded by us as conspecific with I. leucophaeus (Poepp. et Endl.) Koern., known now from Panama, Guiana, Venezuela, Brazil and Peru. I. ovatus Koern. from Brazil is considered by us conspecific with $I$. leucophaeus.

Not mentioned by Pulle was I. arouma (Aubl.) Koern., already collected in Suriname in the 18th century by Rolander and after this collection several times from 1915 onwards. This species has been recorded from the West-Indian Islands, the Guianas and Brazil.

The Ischnosiphon species are known by the native indians under the vernacular name "warimbo" and other names. The splitted stems, especially of $I$. gracilis (Rudge) Koern., but also of I. obliquus (Rudge) Koern. and I. arouma (Aubl.) Koern., are used for basket weaving (Stahel, 1944). 
MONOTAGMA K. Schum.

Of the four species listed by Pulle (1906) M. laxum (Poepp. et Endl.) K. Schum. was included because Kappler 1535 was identified as such, but this specimen appeared to belong to $M$. plurispicatum (Koern.) K. Schum. The genuine $M$. laxum was, however, collected in 1936 by H. E. Rombouts in Suriname at the Upper Sipaliwini River. This species differs from $M$. plurispicatum by the absence of the prominent ring at the base of the pulvinus.

MACBRIDE (1931) pointed out that the well-known M. parkeri (Rosc.) K. Schum., also cited by Pulle, was conspecific with Maranta spicata of Aublet. Consequently the species has to be named Monotagma spicatum (Aubl.) Macbr.

Pulle (1906) described a new species, $M$. surinamense Pulle, that, in our opinion, is conspecific with M. secundum (Peters.) K. Schum.

As already suggested by Amshoff (1948) M. guianense (Koern.) K. Schum., described from French Guiana and cited by Pulle from Suriname, must be considered conspecific with $\mathbf{M}$. plurispicatum (Koern.) K. Schum., described in the same publication (KoERNICKE, 1862) from Brazil, where the species has since then been collected several times. It seemed preferable to maintain the name $M$. plurispicatum (Koern.) K. Schum. as it is better known, and to consider M. guianense (Koern.) K. Schum. a synonym.

As representatives of this family may be of importance for characterizing vegetation units and as the plants do not always flower and as, moreover, the diagnostic characters are often distinguishable only by means of high magnifications, a key based on sterile material would, in our opinion, be desirable. Such a key has been given by LeONARD and Mullenders (1950) for the species of Belgian Congo. The characters used by us for this key were derived from the habit, the kind of pubescence and the shape of the leaf blade, the length of pulvinus and petiole, etc.

1a. Plants provided with a single leaf (seldom 2 leaves); the latter oblanceolate to elliptical, $11-15.5 \mathrm{~cm}$ long and $2.5-5.5 \mathrm{~cm}$ wide; petiole and midrib pilose above.

. . . * . Monophyllanthe oligophylla K. Schum.

b. Plants provided with two or, usually, more leaves . . . 2

$2 a$. Leaves arranged in a rosette at the top of a rather stout stem. 3

$b$. Leaves arranged in a radical rosette or along stem and branches ..... . . . . . . . . . . .

3a. Pulvinus glabrous. Midrib glabrous above. Leaf blade coriaceous, oblique, ovate, $27-46 \mathrm{~cm}$ long and $10-25 \mathrm{~cm}$ wide. . . . . . Ischnosiphon obliquus (Rudge) Koern.

b. Pulvinus pilose above . . . . . . . . . . . . . .

4a. Leaf blade oblique, ovate, excentrically acuminate at the apex and rounded to truncate at the base, $20-51 \mathrm{~cm}$ long and $11-26 \mathrm{~cm}$ wide. . Ischnosiphon arouma (Aubl.) Koern. 
b. Leaf blade almost symmetrical, elliptical, acute to cuneate at the base and acuminate at the apex. . . . . . . .

5a. Leaf sheath coriaceous, $14.5-20 \mathrm{~cm}$ long; petiole $1.5-8 \mathrm{~cm}$ long; pulvinus 2-3 cm long; leaf blade up to $32 \mathrm{~cm}$ long and $9 \mathrm{~cm}$ wide. Plant $1-2 \mathrm{~m}$ high... Ischnosiphon violaceus Pulle

b. Leaf sheath 6-9 cm long; its margin membranous and, in herbarium material, chestnut-coloured; petiole up to $0.7 \mathrm{~cm}$ long or absent; pulvinus $0.7-1.5 \mathrm{~cm}$ long; leaf blade up to 26 $\mathrm{cm}$ long and $5,5 \mathrm{~cm}$ wide. Plant $60-80 \mathrm{~cm}$ high.

Ischnosiphon martianus Eichl. ex Peters.

6a. Leafy and, sometimes, branched stems arising from a radical rosette . . . . . . . . . . . . . . . . . . . .

b. Leaves more or less arranged in a radical rosette; the latter occasionally reduced to one or two leaves; sometimes also with one or more leaves borne at the top of the scape. . . . . 10

7a. Leaf blade oblique, lanceolate to ovate, $7-22 \mathrm{~cm}$ long and 4-9 cm wide, glaucous-pruinose beneath except a, $1 \mathrm{~cm}$ wide, green margin at one side, in herbarium material often chestnut-coloured beneath. Petiole usually absent.

. . . . . . . Ischnosiphon gracilis (Rudge) Koern.

b. Leat blade symmetrical . . . . . . . . . . . . . . .

8a. Leaf blade ovate, acuminate at the apex, rounded to truncate at the base, $15-31 \mathrm{~cm}$ long and $7.5-16.5 \mathrm{~cm}$ wide, glaucouspruinose beneath. Pulvinus $1.5-3.5 \mathrm{~cm}$ long; petiole up to $34 \mathrm{~cm}$ long; leaf sheath 11-26 cm long. . . . . . . . . .

.Ischnosiphon leucophaeus (Poepp. \& Endl.) Koern.

b. Leaf blade ovate-lanceolate, either attenuate, acuminate, or acute at the apex, rounded at the base. Pulvinus up to $11 \mathrm{~mm}$ long; petiole usually very short or absent but occasionally, in the leaves of the rosette, up to $1 \mathrm{~cm}$ long; leaf sheath up to 40 cm long

9a. Sheath and petiole pilose, glabrescent; pulvinus densely pilose. Leaf blade slightly pilose along the midrib, $6-28 \mathrm{~cm}$ long and 5-8 cm wide. Rhizome swollen (arrowroot) . . . . . . .

b. Sheath sparsely pilose; petiole usually absent; pulvinus pilose above. Leaf blade glabrous, 7-24 cm long and 2-12 cm wide; midrib slightly pilose at the base beneath. Rhizome not swollen . . . . . . . . . Maranta divaricata Rosc.

10a. Pulvinus provided with a prominent basal ring. . . . . . 11

b. Pulvinus without basal ring. . . . . . . . . . . 13

11a. Leaf blade slightly oblique, ovate-lanceolate to elliptical, either acute at both ends or the apex slightly acuminate . . . . . . Monotagma secundum (Peters.) K. Schum.

b. Leaf blade distinctly oblique, ovate to ovate-lanceolate, rounded and contracted at the base, excentrically acuminate at the apex . . . . . . . . . . . . . . . . . . 12

12a. Pulvinus and midrib pilose above. Leaf blade pilose along the 
margin, 14-55 cm long and 5-18 cm wide. . . . . . . . . Monotagma plurispicatum (Koern.) K. Schum.

b. Pulvinus pubescent all around; midrib and margin of the leaf blade pilose in the apical half, glabrescent. Leaf blade 25-43 cm long and 9-18 cm wide.

Monotagma spicatum (Aubl.) Macbr.

13a. Pulvinus always longer than $3 \mathrm{~cm}$. Stout, robust herbs . . 14

b. Pulvinus usually shorter than $3 \mathrm{~cm}$. . . . . . . . 19

14a. Joint pilose all around when young; midrib of the leaf blade pilose beneath. Leaf blade lanceolate, apiculate at the apex, rounded and acuminate at the base, $30-68 \mathrm{~cm}$ long and 12-25 $\mathrm{cm}$ wide . . . . . . Calathea comosa (L. f.) Lindl.

b. Pulvinus and midrib glabrous . . . . . . . . . 15

15a. Leaf without sheath (see also Calathea grandis Peters.) Leaf blade elliptical, $30-41.5 \mathrm{~cm}$ long and 9-13.5 cm wide; basal part of the midrib pilose above.. Calathea zingiberina Koern.

b. Sheath present. Midrib glabrous . . . . . . . 16

16a. Leaf blade ovate, 27-84 cm long . . . . . . . . 17

b. Leaf blade elliptical to lanceolate, up to $60 \mathrm{~cm}$ long . . . . 18

17a. Pulvinus 5-10 cm long; sheath unknown. Leaf blade ovate, rounded at the base and, sometimes, near the pulvinus shortly contracted, acute at the apex, $20-74 \mathrm{~cm}$ long and $12-26 \mathrm{~cm}$ wide . . . . . . . . . Calathea grandis Peters.

b. Pulvinus $5.5-16 \mathrm{~cm}$ long; sheath circ. $38 \mathrm{~cm}$ long. Leaf blade ovate or obovate, rounded at the base and near the pulvinus shortly contracted, rounded to obtuse at the apex, $27-150 \mathrm{~cm}$ long and 19-60 cm wide. . Calathea lutea (Aubl.) Spreng.

18a. Leaf blade elliptical, 23-60 cm long and $10-26 \mathrm{~cm}$ wide. Leaf sheath puberulous. . Calathea elliptica (Rosc.) K. Schum.

b. Leaf blade elliptical to lanceolate, 26-55 cm long and 7-22 cm wide. Leaf sheath provided with appressed hairs.

19. - . Calathea altissima (Poepp. \& Endl.) Koern.

19a. Pulvinus always shorter than $1 \mathrm{~cm}$. . . . . . 20

b. Pulvinus (0.5) $1-3 \mathrm{~cm}$ long . . . . . . . . . 27

20a. Leaf sheath leaving a rest of reticulated fibres when decayed. Petiole either absent of up to $1.5 \mathrm{~cm}$ long. Leaf blade chartaceous, cuneate at the base, light coloured beneath; margin involute in herbarium material. . . . . . . . . 21

b. Leaf sheath not leaving a rest of reticulated fibres. . . . 23

21a. Leaf blade glabrous, elliptical, $13-30 \mathrm{~cm}$ long and $3.5-7 \mathrm{~cm}$ wide, acuminate at the apex; sheath 5-28 cm long. . . . . Hylaeanthe polystachya (Pulle) Jonk. \& Jonk.

b. Leaf blade oblanceolate or, sometimes, obovate, $6-11.5 \mathrm{~cm}$ wide .

22a. Leaf blade glabrous, oblanceolate, $20-45 \mathrm{~cm}$ long, distinctly apiculate at the apex.

- Hylaeanthe hexantha (Poepp. \& Endl.) Jonk. \& Jonk.

b. Leaf blade oblanceolate to obovate, 20-25(36) cm long, usually wider and shorter than in the preceding species, not 
or slightly apiculate at the apex; midrib and some of the lateral veins pilose.

Hylaeanthe unilateralis (Poepp. \& Endl.) Jonk. \& Jonk.

23a. Petiole pilose above. Leaf blade falcate, elliptical, acute at both ends, 3-14 cm long and $1.5-4.5 \mathrm{~cm}$ wide. Leaf sheath 2.5-12 cm long; petiole $0.3-14 \mathrm{~cm}$ long. . . . . . . . . - . . . . . . . Calathea micans (Klotzsch) Koern.

b. Leaf blade not falcate, usually larger . . . . . . . 24

24a. Leaf blade elliptical . . . . . . . . . . . . . 25

b. Leaf blade obovate . . . . . . . . . . . . . . 26

25a. Leaf blade $8.5-14.5 \mathrm{~cm}$ long and $3.5 \mathrm{~cm}$ wide, acuminate at the apex and acute at the base, pilose on both surfaces, glabrescent above. Leaf sheath glabrous, 2.5-15 cm long; petiole $0-6 \mathrm{~cm}$ long, densely pilose above.

: . . . . . . . . Myrosma cannifolia L. f.

b. Leaf blade $8.5-24 \mathrm{~cm}$ long and 5-10 cm wide, rounded and acuminate at the apex, rounded at the base; midrib pilose. Leaf sheath sparsely pilose, 7-23 cm long; petiole $0.1-12.5$ cm long, glabrous; pulvinus pilose above.

Maranta humilis Aubl.

26a. Leaf sheaths and cataphylls densely golden-brown at the base; sheath 7-21 cm long; petiole 0-20 cm long, glabrous; pulvinus pilose above. Leaf blade elliptical to oblanceolate, oblique, acuminate at the apex, either rounded or acute at the base, $13-27 \mathrm{~cm}$ long and 4-11.5 cm wide, glabrous above, appressed pilose beneath. . . . . . . Calathea mansonis Koern.

$b$. Leaf sheaths and cataphylls not as densely pilose as in the preceding species. Sheath 3-16 cm long; petiole 0-10 cm long, pilose; pulvinus pilose above. Leaf blade oblanceolate, acuminate to apiculate at the apex and acute to cuneate at the base, 6-33 cm long and 3-14 cm wide. . . . . . . . . . 27a $\dot{\text { Pulvinus }} \cdot$ Calathea propinqua (Poepp. \& Endl.) Koern.

ba. Lulvinus pilose blade subcoriaceous, suborbiculate to broadly elliptical, rounded and excentrically acuminate at the apex and rounded or subacute at the base, $16-27 \mathrm{~cm}$ long and $10-20 \mathrm{~cm}$ wide, pilose at the apex above. Petiole usually absent but occasionally up to $6 \mathrm{~mm}$ long; leaf sheath $12-17.5 \mathrm{~cm}$ long, more or less bi-auriculate at the apex, subcoriaceous . . . . . .

Maranta orbiculata (Koern.) K. Schum.

b. Leaf blade ovate-lanceolate, acute or acuminate at the apex, rounded at the base, glabrous . . . . . . . . . 29

29a. Bracts subtending the inflorescence branches red or purple beneath and green and waxy above, up to $16 \mathrm{~cm}$ long. Petiole glabrous, 7-25 cm long. Leaf blade $38-60 \mathrm{~cm}$ long and up to $20 \mathrm{~cm}$ wide. $\because . . . . . . T h a l i a ~ g e n i c u l a t a \mathrm{~L}$.

b. Bracts subtending the inflorescence branches green, up to 40 $\mathrm{cm}$ long. Petiole up to $23 \mathrm{~cm}$ long. Leaf blade $26-58 \mathrm{~cm}$ long 
and 5.5-24 cm wide . . . . Thalia trichocalyx Gagnep.

30a. Pulvinus pilose all around, hirsute above; petiole puberulous, 16-34 cm long; leaf sheath 7-19 cm long. Leaf blade elliptical, distinctly oblique, maculate above, blue-purple beneath, $13-33 \mathrm{~cm}$ long and $10-17 \mathrm{~cm}$ wide; midrib glabrous above, puberulous beneath . . . . . Calathea legrelleana Reg.

b. Pulvinus pilose above . . . . . . . . . . . . . 3

31a. Leaf blade herbaceous, elliptical, nearly symmetrical, cuneate at the base and cuspidate at the apex, 14-34 cm long and $4.5-8 \mathrm{~cm}$ wide, pilose above, glabrous beneath. Leaf sheath pilose, 16-22 cm long; petiole usually absent. Tubers echinate, edible . . . . . Calathea ovata (Necs \& Mart.) Lindl.

b. Leaf blade usually rounded at the base . . . . . . . 32

32a. Leaf blade herbaceous, oblique, elliptical, glabrous, acuminate at the apex and either acute or rounded and contracted at the base, 23-39 $\mathrm{cm}$ long and 7-13.5 $\mathrm{cm}$ wide, marked with an irregular, light green central zone above, brown purple beneath. Petiole glabrous, $11-57 \mathrm{~cm}$ long; leaf sheath 6-17 cm long, herbaceous. . . . Calathea cyclophora Baker

$b$. Leaf blade coriaceous, distinctly oblique, lanceolate or semiovate, shining above, excentrically and obtusely apiculate at the apex, rounded to truncate at the base, $30-43 \mathrm{~cm}$ long and $9.5-16.5 \mathrm{~cm}$ wide. Petiole absent in the leaf that subtends the inflorescence; its leaf sheath circ. $8 \mathrm{~cm}$ long . . . . . . . . . . . Monotagma laxum (Poepp. \& Endl.) K. Schum.

These investigations have been carried out in the Botanical Museum and Herbarium of the State University of Utrecht, Netherlands (Director: Dr J. Lanjouw). The authors wish to express their best thanks to the directors of the herbaria at Brussel, Genève, Göttingen, Kew, Leiden, München, Paris and Stockholm (Bergius Botanic Garden) for the loan of herbarium specimens. A special word of thanks is due to the directors and staff of the herbaria personally visited by them, viz. Brussel, Leiden and Paris, for the hospitality and assistance given during their stay. The authors are indebted to $\mathrm{Mr} \mathrm{N}$. Y. SANDwith (Kew) and Mr N. W. Simmonds (Trinidad) for valuable information regarding the genus Thalia and to Dr C. E. B. BremeKAMP for the revision of the english text.

\section{REFERENCES}

Amshoff, G. J. H. 1948. Bull. Torr. Bot. Cl. 75: 210-211.

Aublet, F. 1775. Hist. Plant. Guian. Franç. 1: 4.

Dietrigh, D. 1839. Synops. Plant. 1: 6.

GaGnePain, F. 1904. Bull. Soc. Bot. Fr. 51: 180.

Geijskes, D. C. 1942. Met de Oajana's op stap: 74.

Klotzsch, J. F. 1848. in R. Schomburgk, Reisen in Br. Guian. 3: 918, 1125.

Koernicke, F. 1862. Bull. Soc. Imp. Nat. Mosc. 35. 1: 1-147.

Lanjouw, J. \& H. Uitrien. 1940. Rec. Trav. Bot. Néerl. 37: 153.

Leonard, J. \& W. Mullenders. 1950. Bull. Soc. Roy. Bot. Belg. 83: 5-32.

Macbride, J. F. 1931. Field Mus. Nat. Hist., Bot. 11.1: 14. 
Poeppig, E. \& S. Endlicher. 1838. Nov. Gen. Spec. Plant. 2: 19-25.

Pulle, A. A. 1906. Enum. vasc. Pl. Surin.: 109-113.

Pulle, A. A. 1909. Rec. Trav. Bot. Néerl. 6: 253-255.

Schumann, K. 1901. in A. Engler, Das Pflanzenr. 4. 48: 1-184.

Stahel, G. 1944. Dept. Landb. Proefst. Sur. Bull. 59, sec. ed.

Woodson, R. E. 1942. Ann. Missouri Bot. Gard. 29: 333. 